Case report

\title{
A case of montelukast induced hypercholesterolemia, severe hypertriglyceridemia and pancreatitis
}

\author{
Saibal Das ${ }^{a}$, Somnath Mondal ${ }^{\mathrm{b}, \mathrm{f}, *}$, Jayanta Kumar Dey ${ }^{\mathrm{c}}$, Sanjib Bandyopadhyay ${ }^{\mathrm{d}}$, Indranil Saha ${ }^{\mathrm{e}}$, \\ Santanu Kumar Tripathi ${ }^{\mathrm{f}}$ \\ ${ }^{a}$ Nalmuri Block Primary Health Centre, West Bengal 743 502, India \\ ${ }^{\mathrm{b}}$ Pharmacovigilance Programme of India, Indian Pharmacopoeia Commission, Ministry of Health and Family Welfare, Government of India, Ghaziabad 201 002, India \\ ${ }^{\mathrm{C}}$ Department of Ophthalmology, NRS Medical College and Hospital, Kolkata 700 014, India \\ ${ }^{\mathrm{d}}$ Department of Community Medicine, Burdwan Medical College and Hospital, West Bengal 713 104, India \\ ${ }^{\mathrm{e}}$ Department of Psychiatry, Medical College Kolkata, Kolkata 700 073, India \\ ${ }^{\mathrm{f}}$ Department of Clinical and Experimental Pharmacology, Calcutta School of Tropical Medicine, Kolkata 700 073, India
}

\section{A R T I C L E I N F O}

\section{Article history:}

Received 6 April 2013

Accepted 5 June 2013

Available online 6 July 2013

\section{Keywords:}

Allergic rhinitis

Montelukast

Hypercholesterolemia

Hypertriglyceridemia

Pancreatitis

\begin{abstract}
A B S T R A C T

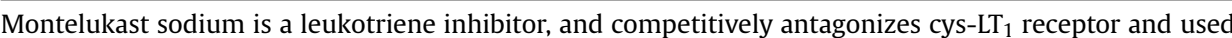
widely and effectively in treating allergic rhinitis, bronchial asthma and allied respiratory conditions. This case report outlines a rare case of montelukast induced hypercholesterolemia, severe hypertriglyceridemia and acute pancreatitis in a 22 years old male patient. The patient was taking $10 \mathrm{mg}$ oral montelukast daily for allergic rhinitis. Although his symptoms improved considerably, after 2 months of therapy, he experienced unusual weight gain and got admitted with severe pain abdomen. Clinical and other relevant investigation findings revealed the presence of acute pancreatitis with associated hypercholesterolemia and severe hypertriglyceridemia. There were no evidences of any other possible hereditary, surgical, metabolic, infective, organic or other pathologic causes giving rise to these conditions. De-challenge was done and the patient was treated conservatively resulting in reversal of the diseased state. Naranjo adverse drug reaction probability scale suggested that it was 'probable' that oral administration of montelukast was responsible for the acute pancreatitis associated with hypercholesterolemia and severe hypertriglyceridemia. There is only a singular and confirmed reported case of montelukast induced hypertriglyceridemia from India. For patients taking montelukast for a long duration, routine lipid profile monitoring should be done, and if these patients present with symptoms of epigastric and periumbilical pain with vomiting, provisions for screening acute pancreatitis might be warranted.
\end{abstract}

Copyright @ 2013 , InPharm Association, Published by Reed Elsevier India Pvt. Ltd. All rights reserved.

\section{Introduction}

Montelukast sodium is a leukotriene inhibitor, and competitively antagonizes cys- $\mathrm{LT}_{1}$ receptor mediated bronchoconstriction, increased vascular permeability and recruitment of eosinophils in patients with bronchial asthma. It is used widely and effectively in treating allergic rhinitis, bronchial asthma and allied respiratory conditions. Its common adverse reactions include headache, rashes, gastrointestinal disturbances, sleep disorders, eosinophilia, neuropathy and very rarely Churg Strauss syndrome. In 2009, the Food and Drug Administration (FDA) concluded their review into the

\footnotetext{
* Corresponding author. Department of Clinical and Experimental Pharmacology, Calcutta School of Tropical Medicine, 108, CR Avenue, 3rd Floor, Kolkata 700 073, West Bengal, India. Tel.: +919874124575, +91 3322573598.
}

E-mail addresses: somu1159@gmail.com, somcology@gmail.com (S. Mondal). possibility of neuropsychiatric side effects with leukotriene modulator drugs. Although clinical trials only revealed an increased risk of insomnia, post-marketing surveillance showed that the drugs are associated with a possible increase in suicidal behavior and other side effects like agitation, aggression, anxiousness, dream abnormalities and hallucinations, irritability, tremor, depression and restlessness. ${ }^{1,2}$

This case report outlines a rare case of montelukast induced hypercholesterolemia, severe hypertriglyceridemia and acute pancreatitis in a 22 years old male patient.

\section{Case summary}

A 22 years old male patient (body weight $64 \mathrm{~kg}$ ) was suffering from allergic rhinitis and was prescribed $10 \mathrm{mg}$ oral montelukast daily after food. He was symptomatically improved by the drug and 
continued taking it prophylactically. After 1.5 months of therapy, he experienced gradually increased abdominal fat deposition and recorded an unusual weight gain by $7 \mathrm{~kg}$. At the end of 2 months, he presented in the emergency with acute abdominal pain and vomiting. The pain was gradual in onset, dull and steady, located around the epigastrium and periumbilical region, radiating toward back and associated with abdominal distension.

Physical examination revealed a generalized distressed state with a pulse rate of $96 /$ minute and blood pressure $112 / 72 \mathrm{~mm}$ of $\mathrm{Hg}$. His body weight was $73 \mathrm{~kg}$. There was no evidence of jaundice or erythematous skin nodules. Abdominal examination revealed presence of striae. Abdomen was severely tender with muscle guarding. Bowel sounds were diminished. Relevant blood and other investigations done at that time are enumerated in Table 1.

These clinical features coupled with blood and other investigations highly suggested it to be diagnosed as a case of severe acute pancreatitis (by Ranson's criteria ${ }^{3}$ ) associated with hypercholesterolemia and severe hypertriglyceridemia.

It appears from the blood investigation reports, abdominal ultrasonography findings and computed tomography report that the patient had an acute pancreatitis, associated with hypercho lesterolemia and severe hypertriglyceridemia. The ECG findings showed some non-specific ST changes which might be due to associated hypocalcemia.

The patient was never on oral montelukast therapy earlier. Before initiation of this drug, he was otherwise normal, except for symptoms of allergic rhinitis. He was non-alcoholic and dietary habit was regular and normal. He maintained a sedentary life style with moderate physical activities.

Factitious pancreatitis was ruled out. There were no evidences of any other intra-abdominal pathology like biliary tract disease, peritonitis, peptic ulcer perforation, intestinal obstruction or appendicitis. Ultrasonography of abdomen finding did not show any evidence of gallstones. There was no history of any abdominal trauma, head injury, any surgery or any operative procedure like Endoscopic Retrograde Cholangiopancreatography (ERCP).

There was no history of any concomitant medications. 3 months back, he took oral ranitidine $300 \mathrm{mg}$ daily for 2 weeks for symptoms of gastritis, after which he was not on any other medications before initiating montelukast.

The patient was also not having any infections like coxsackievirus, cytomegalovirus, Epstein-Barr virus, Human Immu

Table 1

Investigation results during the acute illness and recovery.

\begin{tabular}{|c|c|c|c|c|c|c|}
\hline \multicolumn{7}{|c|}{ Blood investigation reports } \\
\hline \multicolumn{2}{|c|}{ Serial nos. } & \multicolumn{3}{|c|}{ Parameters detected } & $\begin{array}{l}\text { Detected values during } \\
\text { acute illness }\end{array}$ & $\begin{array}{l}\text { Detected values } \\
\text { during recovery }\end{array}$ \\
\hline \multicolumn{2}{|l|}{1} & \multicolumn{3}{|c|}{ Hemoglobin } & $12.8 \mathrm{~g} / \mathrm{dL}$ & $12.7 \mathrm{~g} / \mathrm{dL}$ \\
\hline 2 & & \multicolumn{3}{|c|}{ Total WBC count } & $17800 / \mu \mathrm{L}$ & $11900 / \mu \mathrm{L}$ \\
\hline 3 & & \multicolumn{3}{|c|}{ ESR } & $40 \mathrm{~mm}$ after $1 \mathrm{st}$ hour & $26 \mathrm{~mm}$ after $1 \mathrm{st}$ hour \\
\hline 4 & & \multicolumn{3}{|c|}{ Fasting blood glucose } & $166 \mathrm{mg} / \mathrm{dL}$ & $135 \mathrm{mg} / \mathrm{dL}$ \\
\hline 5 & & \multicolumn{3}{|c|}{$\begin{array}{l}2 \mathrm{~h} \text { postprandial } \\
\text { blood glucose }\end{array}$} & $211 \mathrm{mg} / \mathrm{dL}$ & $152 \mathrm{mg} / \mathrm{dL}$ \\
\hline 6 & & \multicolumn{3}{|c|}{ Serum urea } & $13.9 \mathrm{mg} / \mathrm{dL}$ & \\
\hline 7 & & \multicolumn{3}{|c|}{ Serum creatinine } & $0.7 \mathrm{ng} / \mathrm{mL}$ & \\
\hline 8 & & \multicolumn{3}{|c|}{ Serum sodium } & $138 \mathrm{meq} / \mathrm{L}$ & \\
\hline 9 & & \multicolumn{3}{|c|}{ Serum potassium } & $4.3 \mathrm{meq} / \mathrm{L}$ & \\
\hline 10 & & \multicolumn{3}{|c|}{ Serum calcium } & $7.8 \mathrm{mg} / \mathrm{dL}$ & $8.9 \mathrm{mg} / \mathrm{dL}$ \\
\hline 11 & & \multicolumn{3}{|c|}{ Serum amylase } & $311 \mathrm{U} / \mathrm{L}$ & $81 \mathrm{U} / \mathrm{L}$ \\
\hline 12 & & \multicolumn{3}{|c|}{ Serum lipase } & $163 \mathrm{U} / \mathrm{L}$ & $38 \mathrm{U} / \mathrm{L}$ \\
\hline 13 & & \multicolumn{3}{|c|}{$\begin{array}{l}\text { Serum lactate } \\
\text { dehydrogenase }\end{array}$} & $177 \mathrm{U} / \mathrm{L}$ & \\
\hline \multirow[t]{5}{*}{14} & & \multirow{5}{*}{\multicolumn{2}{|c|}{ Serum lipid profile }} & Total cholesterol & $264.9 \mathrm{mg} / \mathrm{dL}$ & $183.6 \mathrm{mg} / \mathrm{dL}$ \\
\hline & & & & LDL cholesterol & $108.2 \mathrm{mg} / \mathrm{dL}$ & $88.2 \mathrm{mg} / \mathrm{dL}$ \\
\hline & & & & HDL cholesterol & $44.6 \mathrm{mg} / \mathrm{dL}$ & $43.4 \mathrm{mg} / \mathrm{dL}$ \\
\hline & & & & VLDL cholesterol & $112.1 \mathrm{mg} / \mathrm{dL}$ & $52.0 \mathrm{mg} / \mathrm{dL}$ \\
\hline & & & & Triglyceride & $560.5 \mathrm{mg} / \mathrm{dL}$ & $260.0 \mathrm{mg} / \mathrm{dL}$ \\
\hline \multirow[t]{8}{*}{15} & & \multicolumn{2}{|c|}{ Liver function tests } & Total bilirubin & $0.7 \mathrm{mg} / \mathrm{dL}$ & \\
\hline & & & & Direct bilirubin & $0.3 \mathrm{mg} / \mathrm{dL}$ & \\
\hline & & & & Indirect bilirubin & $0.4 \mathrm{mg} / \mathrm{dL}$ & \\
\hline & & & & Serum glutamic oxaloacetic transaminase (SGOT) & $64 \mathrm{U} / \mathrm{L}$ & \\
\hline & & & & Serum glutamic pyruvic transaminase (SGPT) & $53 \mathrm{U} / \mathrm{L}$ & \\
\hline & & & & Alkaline phosphatase & $136 \mathrm{IU} / \mathrm{L}$ & \\
\hline & & & & Albumin & $4.3 \mathrm{~g} / \mathrm{dL}$ & \\
\hline & & & & Globulin & $3.0 \mathrm{~g} / \mathrm{dL}$ & \\
\hline \multicolumn{7}{|c|}{ Other investigation reports } \\
\hline \multicolumn{3}{|c|}{$\begin{array}{l}\text { Serial Investigations } \\
\text { nos. }\end{array}$} & \multicolumn{2}{|c|}{ Findings during acute illness } & \multicolumn{2}{|l|}{ Findings during recovery } \\
\hline 1 & \multicolumn{4}{|c|}{12 lead electrocardiography Non-specific ST changes } & & \\
\hline 2 & \multicolumn{4}{|c|}{$\begin{array}{l}\text { Straight skiagram (X-ray) of Presence of some air in the duodenal C-loop } \\
\text { abdomen in erect posture }\end{array}$} & & \\
\hline 3 & \multicolumn{2}{|c|}{$\begin{array}{l}\text { Ultrasonography (USG) } \\
\text { of whole abdomen }\end{array}$} & $\begin{array}{l}\text { Edem } \\
\text { textur } \\
\text { body } \\
\text { No evi }\end{array}$ & $\begin{array}{l}\text { ancreas, with increased volume and heterogenous echo } \\
\text { ence of pancreatic head enlargement and edema along the } \\
\text { reas. There was some peripancreatic free fluid collection. } \\
\text { of gall bladder pathology was found }\end{array}$ & $\begin{array}{l}\text { Slight edematous pancre } \\
\text { echogenicity and no peri }\end{array}$ & $\begin{array}{l}\text { heterogenous } \\
\text { ic fluid collection }\end{array}$ \\
\hline 4 & Upp & doscopy & Withir & al limits & & \\
\hline 5 & $\begin{array}{l}\text { Com } \\
\text { scan }\end{array}$ & $\begin{array}{l}\text { omography (CT } \\
\text { omen }\end{array}$ & $\begin{array}{l}\text { Diffus } \\
\text { irregu } \\
\text { of acu }\end{array}$ & $\begin{array}{l}\text { gement of pancreas with heterogenous enhancements and } \\
\text { rgins with intraperitoneal free fluid collection, suggestive } \\
\text { creatitis. No evidence of pancreatic pseudocyst or abscess }\end{array}$ & $\begin{array}{l}\text { Slight enlargement of par } \\
\text { mild edema. No intraperi }\end{array}$ & $\begin{array}{l}\text { ith regular borders and } \\
\text { ree fluid collection }\end{array}$ \\
\hline
\end{tabular}


nodeficiency Virus (HIV), echovirus or other parasites. Also there were no evidences of parotitis, sialadenitis or eating disorders. He was not an immune compromised or a transplant recipient, where cytomegalovirus induced pancreatitis is common. So, all these virological infections could be ruled out.

There was no history of hereditary pancreatitis or obesity in the family. The patient was did not have any co-morbidities like cystic fibrosis, any vasculitis, connective tissue disorders, any autoimmune disorders like Sjogren's syndrome or hematologic disorders like thrombotic thrombocytopenic purpura (TTP). There were no evidences of carcinoma pancreas, periampullary diverticulum, pancreas division, metabolic acidosis, diabetes mellitus or renal failure.

The patient was admitted and montelukast was withdrawn immediately upon suspicion and the patient was treated conservatively with intravenous fluids, analgesics and no oral alimentations. Amoxicillin and metronidazole were used as prophylactic antibiotics. The patient's condition started improving from the next 7 days. Pain abdomen and vomiting were relieved considerably and gradually oral feeding was commenced on the 11th day post admission. Biochemical tests and other investigations were done routinely during follow up. Clinical symptoms improved totally within 14 days and the patient was then discharged. Relevant investigation reports done during discharge are shown in Table 1.

De-challenge revealed that hypercholesterolemia, hypertriglyceridemia and acute pancreatitis was montelukast induced and no other immunological processes were possibly involved in the process. No specific immunological tests were done.

After the next 1 month the patient recorded his body weight as $66 \mathrm{~kg}$. The symptoms of allergic rhinitis however returned again after 3 weeks of cessation of montelukast, for which he was started treatment with $5 \mathrm{mg}$ oral levocetirizine daily with well response. Obviously, no re challenge with oral montelukast was done.

\section{Discussion and conclusion}

There is only a singular reported case of montelukast induced hypertriglyceridemia from India, ${ }^{4}$ other reports about montelukast induced pancreatitis are extremely rare and non-confirmatory. ${ }^{5}$ On the contrary, it has been observed that cysteinyl leukotrienes may be involved in the pathogenesis of acute pancreatitis and cysteinyl leukotriene receptor antagonist, montelukast, might be of therapeutic and protective value for treatment of acute pancreatitis. ${ }^{6}$ However in chronic pancreatitis, studies indicate that there was no significant effect of montelukast in prognosis. ${ }^{7}$

In this case, features of acute pancreatitis with weight gain, hypercholesterolemia, and severe hypertriglyceridemia were evident within 2 months of oral montelukast mono therapy in a patient who had not been exposed to this drug earlier. Acute pancreatitis might have been precipitated more by co-existing hypertriglyceridemia. 8,9 Also these symptoms were resolved on discontinuation of the drug and different investigation reports verified reversal of the diseased process. So, this is a very rare adverse drug reaction of oral montelukast, itself causing acute pancreatitis, associated with hypercholesterolemia, and severe hypertriglyceridemia.

Naranjo adverse drug reaction probability scale ${ }^{10}$ suggested that there was a 'probable' relationship between administration of montelukast and acute pancreatitis, associated with hypercholesterolemia, and severe hypertriglyceridemia. For patients taking montelukast for a long duration, routine lipid profile monitoring may be warranted to check for abnormalities, and these patients presenting with symptoms of epigastric and periumbilical pain with vomiting should arouse suspicion for acute pancreatitis. There should be provisions of early withdrawal of the offending drug and immediate emergency management.

\section{Conflicts of interest}

All authors have none to declare.

\section{References}

1. Undem BJ. Pharmacotherapy of asthma. In: Brunton L, Parker K, Blumenthal D, Buxton I, eds. Goodman E' Gilman's The Pharmacological Basis of Therapeutics. 11th ed. New York: McGraw-Hill; 2006;27:462-474.

2. Tripathi KD. Anticholinergic drugs and drugs acting on autonomic ganglia. In: Tripathi M, ed. Essentials of Medical Pharmacology. 5th ed. New Delhi: Jaypee Brothers Medical Publishers (P) Ltd; 2003;15:195-209.

3. Ranson Criteria. (online) from Wikipedia, the free encyclopedia. Last Modified on 4 January 2013 at 20.23. http://en.wikipedia.org/wiki/Ranson_criteria; Accessed 23.01.13.

4. Palodhi S, Ray Chaudhuri P, Biswas A, Bera T. Montelukast induced hypertriglyceridemia. Indian Med Gaz; 2012 Aug:334-336.

5. Could Montelukast Sodium Cause Pancreatitis? A Study of 15 Users. (online) (c) 2013 eHealthMe.com. http://www.ehealthme.com/ds/montelukast+sodium/ pancreatitis; Accessed 2.02.13.

6. Ozkan E, Akyüz C, Sehirli AO, Topaloğlu U, Ercan F, Sener G. Montelukast, a selective cysteinyl leukotriene receptor 1 antagonist, reduces cerulein-induced pancreatic injury in rats. Pancreas. 2010 Oct;39:1041-1046.

7. Cartmell MT, O'Reilly DA, Porter C, Kingsnorth AN. A double-blind placebocontrolled trial of a leukotriene receptor antagonist in chronic pancreatitis in humans. J Hepato-biliary-pancreatic Surg. 2004 Aug;11:255-259.

8. Tsuang W, Navaneethan U, Ruiz L, Palascak JB, Gelrud A. Hypertriglyceridemic pancreatitis: presentation and management. Am J Gastroenterol. 2009 Apr;104: 984-991.

9. Gelrud A, Whitcomb DC. Hypertriglyceridemia-Induced Acute Pancreatitis. (online) Wolters Kluwer Health. (c) 2013 UpToDate, Inc. http://www.uptodate. com/contents/hypertriglyceridemia-induced-acute-pancreatitis; Accessed 2.01.13.

10. Naranjo CA, Busto U, Sellers EM, et al. A method for estimating the probability of adverse drug reactions. Clin Pharmacol Ther. 1981 August;30:239-245. 